\title{
Public Procurement as a Tool for the Protection and Promotion of Human Rights: A Study of Collaboration, Due Diligence and Leverage in the Electronics Industry
}

\author{
Olga MARTIN-ORTEGA*
}

\begin{abstract}
This article explores the innovative use of public procurement as a tool to respect, protect and promote human rights by capitalizing on the significant leverage that public buyers have over corporate practices in their supply chain. It provides an analysis of Electronics Watch, an organization that focuses on the role of states' own procurement practices as central to the state duty to protect the human rights of those who are affected by its activities as an economic actor. Through the assessment of the Electronics Watch model this article argues that by bringing together the economic leverage of public buyers and corporate human rights due diligence, one can create transformative tools for the improvement of working conditions in global supply chains.
\end{abstract}

Keywords: corporate human rights due diligence, electronics industry, global supply chain, human rights, labour rights, public procurement

\section{INTRODUCTION}

Public buyers, as large scale consumers of goods, hold significant leverage over the behaviour of brands and retailers in global supply chains. While states tend to use their discretion to promote domestic social issues through public procurement, this has rarely been used to influence conditions of those outside their jurisdiction: ${ }^{1}$ those working to produce the goods they purchase. The use of public procurement as a tool for the promotion and protection of human rights in supply chains is underdeveloped both in theory and practice.

Initiatives for the improvement of human rights in the context of global production of goods have mainly focused on the responsibilities of the companies involved in

* Reader in Public International Law, School of Law, University of Greenwich, Old Royal Naval College, Park Row, London SE10 9LS, UK (email: o.martin-ortega@gre.ac.uk). The author is grateful to Björn Claeson for his comments and corrections; to Anita Ramasastry for her invaluable suggestions and to Jim Cranshaw for embarking her in the great adventure of improving human rights in the electronics supply chain.

1 Robert Stumberg, Anita Ramasastry and Meg Roggensack, 'Turning a Blind Eye? Respecting Human Rights in Government Purchasing', ICAR, 2014; Claire Methven O’Brien, Amol Mehra, Marta Andrecka and Nicole Vander Meulen, 'Public Procurement and Human Rights: A Survey of Twenty Jurisdictions', International Learning Lab on Public Procurement, 2016, p. 20, http://www.hrprocurementlab.org/wp-content/uploads/2016/06/Public-Procurementand-Human-Rights-A-Survey-of-Twenty-Jurisdictions-Final.pdf (accessed 1 April 2017). 
the manufacturing and commercialization of consumer products, on the one hand, and states' obligations to regulate working conditions under their jurisdiction, on the other. In the past two decades both these approaches have yielded limited results. Over-reliance on private power to self-regulate has not brought substantial change to working conditions in supply chains and the promise of multi-stakeholder initiatives as alternatives has also fallen short of expectations. ${ }^{2}$ Equally, the focus on the states where production is located has had restricted results in the improvement of human rights standards. The United Nations Guiding Principles on Business and Human Rights (the UNGPs) ${ }^{3}$ have helped to move the debate over human rights in supply chains forward, establishing a foundation for normative and policy development. They have also served as an important catalyst for action at state, industry and civil society level, pushing attention back to the state - especially home states, while still maintaining expectations of the corporate sector.

This article argues that there are key changes coming in transnational law and practice in this sector, and it is just a matter of time before states articulate their human rights obligations in relation to corporate human rights impacts through public procurement. Initiatives such as Electronics Watch, at the centre of this analysis, contributes to this trend. The model of the organization is based on providing a platform that harnesses the power of collaboration and alignment of interests among companies to exercise leverage in their supply chains. This will ultimately transform such chains through increased human rights due diligence.

This article provides an analysis of the operational and legal context in which Electronics Watch has been developed and commenced its activity. It analyses why this is an innovative approach and points at current implementation challenges that need to be addressed to make such collaborative models effective as one of many much-needed solutions to the problems of human rights abuses in global supply chains. Given Electronics Watch's initial focus on Europe, this article considers principally the European Union (EU) normative framework and developments.

\section{The State-Business Nexus: Public Procurement as a Business AND Human Rights ToOL}

Public (government) procurement offers a potentially valuable contribution to the search for strategies to improve human rights in global supply chains. It can be a powerful economic instrument to create market demand for responsibly manufactured goods. Public procurement contracts worldwide are estimated to be worth $€ 2$ trillion annually. ${ }^{4}$

\footnotetext{
2 See, for example, Richard M Locke, The Promise and Limits of Private Power: Promoting Labor Standards in a Global Economy, New York (Cambridge University Press, 2013); Richard Locke, Thomas Kochan and Fei Qin, 'Beyond Corporate Codes of Conduct: Work Organization and Labour Standards at Nike's Suppliers' (2007), 146 International Labour Review; Richard Locke, Ben A Rissing and Timea Pal, 'Complements or Substitutes? Private Codes, State Regulation and the Enforcement of Labour Standards in Global Supply Chains', (2013) 51(3) British Journal of Industrial Relations 519-52.

3 Human Rights Council, 'Guiding Principles on Business and Human Rights: Implementing the United Nations “Protect, Respect and Remedy” Framework' (Guiding Principles), A/HRC/17/31 (21 March 2011).

4 European Union, DG Grow, 'Public Procurement Indicators 2015', DG GROW G4 - Innovative and e-Procurement, 10 December 2016.
} 
Governments in OECD (Organisation for Economic Co-operation and Development) member states spend on average $12 \%$ of their gross domestic product (GDP) on public procurement $^{5}$ and an average of $16 \%$ in the $\mathrm{EU}^{6}$ and $20 \%$ worldwide. $^{7}$

The UNGPs contemplate states using their purchasing power to promote corporate respect for human rights. UNGPs 4 to 6 seek to build on the traditional duty of states to protect the human rights of those affected by third party interference. This is expressed in UNGP 4 by defining what is referred to as the 'state-business nexus'. By doing this, the UNGP increases the focus on a critical role of the state, beyond regulating companies in their jurisdiction or incorporated in their territory: the state itself as an element of the production system. While UNGP 4 focuses on state-owned companies, the subsequent UNGPs 5 and 6 contain direct references to statute duty to protect human rights as applicable to situations where a state contracts with business entities. ${ }^{8}$ Generally, states 'should promote respect for human rights by business enterprises with which they conduct commercial transactions' and this includes through public procurement (UNGP 6 Commentary). This Principle therefore can be understood as establishing a link between the obligations of the state to respect, protect and promote human rights and public procurement. This has been interpreted as extending a state's obligations to protect human rights in its own supply chains. ${ }^{9}$

The application of socially responsible public procurement for the protection of human rights, especially regarding the supply chain, is not as straightforward as the UNGPs may lead one to believe. There are two issues that are recurring general obstacles. First, the international public procurement regime was created to protect against anti-competitive practices and discrimination and was based on a narrowly defined 'value for money' concept rather than a system that initially factors in social considerations. ${ }^{10}$ Second, the existing practice on socially responsible procurement has been mostly limited to domestic human rights protection and makes it challenging to extend social clauses to workers beyond the borders of the buying state. ${ }^{11}$

\footnotetext{
5 OECD, 'Size of Public Procurement Market' (2011), Government at a Glance, 148.

6 European Commission, DG Trade website, Public Procurement in a Nutshell [undated], http://ec.europa.eu/trade/ policy/accessing-markets/public-procurement/ (accessed 1 February 2017).

7 World Bank Group, 'Benchmarking Public Procurement 2016: Assessing Public Procurement Systems in 77 Economies,' Washington, 2016.

8 With regard to services the UNGPs are more specific, establishing that states should 'exercise adequate oversight in order to meet their international human rights obligations when they contract with, or legislate for, business enterprises to provide services that may impact upon the enjoyment of human rights'. On state obligations and services see, for example, Claire Methven O'Brien, 'Essential Services, Public Procurement and Human Rights in Europe' (2015), University of Groningen, http://papers.ssrn.com/sol3/papers.cfm?abstract_id=2591898\#\# (accessed 1 April 2017).

9 Methven O'Brien, Mehra, Andrecka and Vander Meulen, note 1.

10 The main international instrument on public procurement is the World Trade Organization's Plurilateral Agreement on Government Procurement (GPA). The purpose of this international framework is to establish a fair system for providing goods and services to public authorities through the application of rules on transparency, non-discrimination and fair competition. The EU is party to this Agreement. Within this framework the emphasis has been placed on the concept of 'value for money', narrowly defined to exclude most social considerations, and the aim of promoting free trade and competition.

11 Procurement to achieve social aims has been used since the nineteenth century, within the framework of the welfare state, mainly to achieve horizontal policies linked with domestic employment policies such as fighting discrimination, promoting local and inclusive employment and manufacturing (e.g., veterans, disabled people and long-term unemployed). See Christopher McCrudden, Buying Social Justice. Equality, Government Procurement and Legal Change (Oxford: Oxford University Press, 2007).
} 
This is nevertheless not a barrier for an increasing normative and practice development on the use of public procurement to articulate secondary objectives that seek to prevent human rights abuses abroad. ${ }^{12}$ Current normative developments seem to be opening avenues for future practice. In the United States, for example, the Federal Acquisition Regulation (FAR) prohibits selling a product sourced abroad through federal contracts that is mined, produced or manufactured with forced child labour. ${ }^{13}$ The UK Modern Slavery Act (2015) requires some public buyers to report on their efforts to prevent modern slavery, human trafficking and forced labour in their supply chain. ${ }^{14}$

Current EU regulation on public procurement does not directly address the issue of human rights. However, as discussed below, the relatively new 2014 EU procurement regime provides important opportunities to articulate public procurement as a human rights mechanism. As a member of the World Trade Organization (WTO) and signatory of its General Procurement Agreement, the EU follows the same free trade focused principles in its regulation of public procurement, ${ }^{15}$ and whilst the EU corporate social responsibility (CSR) agenda has attempted to rely on public procurement as a potential tool to advance human rights protection in the realm of corporate activity, this is not reflected in the procurement regulation. ${ }^{16}$ The EU current public procurement regulations are contained, principally, in the Public Procurement Directive (2014/24/EU). ${ }^{17}$ This regulation is strongly rooted within the principles of non-discrimination and freedom of competition.

The reforms brought by the new 2014 Directive have increased flexibility for the inclusion of social objectives as part of procurement processes by including references to the importance of integration of environmental, social and labour requirements into public procurement procedures throughout its text, widening the potential use of social labelling and including requirements to comply with the core International Labour Organization (ILO) Conventions. ${ }^{18}$

\footnotetext{
12 Methven O'Brien, Mehra, Andrecka and Vander Meulen, note 1.

13 Federal Acquisition Regulation (FAR), 48 CFR $\$ 101$ et seq, at 22.15 (Prohibition of Acquisition of Products Produced by Forced or Indentured Child Labour).

14 Modern Slavery Act (2015), Section 54 Transparency in Supply Chains, etc. This section imposes the obligation on commercial organizations which turn over a certain threshold (established currently at $£ 36$ million) to produce an annual slavery and human trafficking report. Certain bodies subjected to public procurement regulation are considered to be commercial organizations for the purposes of Section 54, including most universities.

15 In the framework of the EU, all public sector authorities, whatever the procurement, are subject to the Treaty on the Functioning of the European Union (TFEU), most significantly in relation to rules on equal treatment, freedom of establishment, and freedom to provide services. This means that at the very least, contracting entities must act transparently and must treat all bidding parties equally, proportionately and without discrimination.

16 Olga Martin-Ortega and Muzaffer Eroglu, 'The European Union's Corporate Social Responsibility Strategy: a Pole of Excellence?' in Jan Orbie and Lisa Torrell (eds), The European Union and Social Dimension of Globalisation (Oxon: Routledge, 2008); Opi Outhwaite and Olga Martin-Ortega, 'Human Rights in Global Supply Chains: Corporate Social Responsibility and Public Procurement in the European Union' (2016) 10:1 Human Rights and Legal Discourse 41.

17 The Directive only applies to public contracts above the specified economic threshold, therefore national legislators are free to regulate public procedures for lower amounts in different ways from those specified in the Directives, as long as they comply with EU Treaty provisions.

18 See Olga Martin-Ortega, Opi Outhwaite and William Rook, 'Buying Power and Working Conditions in the Electronics Supply Chain: Legal Options for Socially Responsible Public Procurement' (2015) 19 International Journal of Human Rights, 341-68; and Outhwaite and Martin-Ortega, note 16.
} 


\section{The Cost of a Phone: Human Rights in the Electronics INDUSTRY SuPPLy Chain}

The electronics industry supply chain is a very complex and multilevel one, as are most of current global systems of good production. ${ }^{19}$ Scholar Richard Locke titled one of his authoritative works: 'We Live in a World of Global supply Chains'. ${ }^{20}$ According to Locke, this world links thousands of companies, 'large and small, across multiple cultural and political boundaries'. ${ }^{21}$ The ILO estimates that by 2013 there were some 453 million global supply chain-related jobs in 40 countries which cover approximately twothirds of the global labour force. This represents 85 per cent of world GDP. ${ }^{22}$ The human rights of millions of people are directly related to the way these chains are organized and demand and supply flows through them. This section focuses on the rights of those who manufacture components and assemble the products.

The electronics industry is heavily focused on its end consumers. International brands are highly exposed to market demand and dependent on corporate image and consumer perception. $^{23}$ 'Brands' are well-known companies, with headquarters mostly in developed countries. They are highly valuable enterprises, with hardware producers featuring among the highest global revenue producing companies. ${ }^{24} \mathrm{~A}$ single product may contain components involving work carried out by several companies in multiple countries. Brands themselves tend to carry out little or no manufacturing. ${ }^{25}$ They conceive a product, develop essential elements such as software, initiate production and carry out product design and branding. Complex elements of the electronics goods may be produced in countries where highly specialized hubs are located but most of the manufacturing and assembling takes place in low-cost, labour-intensive production sites in developing countries. ${ }^{26}$

Component manufacturing and assembly is carried out by contracted manufacturers which tend, in turn, to be large enterprises themselves, with many employees in multiple locations, generally in developing countries. ${ }^{27}$ However, they also

\footnotetext{
19 OECD, 'Mapping Global Value Chains'. Report TAD/TC/WP/RD(2012)9, 2012, 27-29.

20 Richard Locke, 'We Live in a World of Global Supply Chains' in Dorothee Baumann-Pauly and Justine Nolan (eds), Business and Human Rights. From Principles to Practice (Oxon: Routledge, 2016) 299.

21 Ibid.

22 ILO, Non-standard forms of employment. Report for discussion at the Meeting of Experts on Non-Standard Forms of Employment (Geneva, 16-19 February 2015), International Labour Office, Geneva, 2015.

23 The electronics industry supply chain extends from the extraction of raw materials to the manufacture and assembly of products at large factories contracted by global brands and beyond to the management of waste and recycling of products and components. There are human rights concerns in all of these parts of the chain, with extraction, trade, processing and transportation of raw materials - including the so-called 'conflict minerals' - attracting important attention in the past years. This article focuses only on the upper levels of the supply chain where products and components are manufactured and assembled.

24 Interbrand, Best Global Brands 2015, http://interbrand.com/best-brands/best-global-brands/2015/ranking/ (accessed 1 April 2017). In this report, the top 10 companies include Apple Inc. (the world most profitable enterprise), Google, Microsoft, IBM, Samsung and Intel.

25 Locke, note 2, pp 6-7.

26 See, for example, ILO, Ups and Downs in the Electronics Industry: Fluctuating Production and the Use of Temporary and Other Forms of Employment, GDFACE/2014, International Labour Office, Geneva, 2014.

27 OECD, 'Mapping Global Value Chains', note 19, 28. FoxConn, Flextronics and Inventec are examples of those. This is the case in most supply chains. In fact, as described by Mayer and Gereffi, by 2000, 50 per cent of the world's manufacturing production was located in developing countries and this trend has only increased over the last decade;
} 
subcontract the manufacturing of specific components, which form part of the final product. $^{28}$ These subcontractors, which produce the components and finished electronic goods, often employ vast numbers of people to work on their production lines. A significant proportion of this manufacturing takes place in China and East Asia. ${ }^{29}$ The extraordinary growth of producing companies, such as Foxconn in China, is built on its 'cheap, big, fast and efficient production model' ${ }^{30}$ China is by far the largest producer of electronics goods worldwide but electronics factories are also present in many other jurisdictions, including Mexico, Brazil, Taiwan, Malaysia, the Philippines, Vietnam, Indonesia, Thailand, India and Eastern Europe - mostly Poland, the Czech Republic and Hungary. $^{31}$

The electronics industry is under significant consumer and investor pressure to innovate and to bring new products to the market. This translates into pressure on all elements of the global supply chain to increase productivity, shrink lead-times and reduce costs in order to maintain a supply chain flexible enough to respond to peaks of demand and innovation. At the manufacturing level, this has led to the industry being a high-risk sector for human rights violations, including forced labour and human trafficking. ${ }^{32}$ Manufacturing and assembling is characterized by intensive labour, demanding a 'very flexible' and low skilled workforce able to carry out tiring and repetitive work - and on occasions, tasks that pose a significant risk to worker health. ${ }^{33}$ The requirement of a 'flexible' workforce usually covers up a system in which workers work without job security or predictability, which would allow them to plan, save and organize their own family life. This is reinforced by the different domestic legal mechanisms by which the employer (factory)-employee relationship is undermined in the industry. These include temporary agency workers, subcontracted workers and student intern workers. ${ }^{34}$ In 2016, an ILO study concluded that about $80-90 \%$ of the

(F'note continued)

Frederick Mayer and Gary Gereffi, 'Regulation and Economic Globalization: Prospects and Limits of Private Governance', (2010), 12 Business and Politics.

28 Good Electronics, Reset. 'Corporate Social Responsibility in the Global Electronics Supply Chain' (2009), 19, https://goodelectronics.org/publications-en/Publication_3248 (accessed 1 April 2017).

29 Timothy J Sturgeon and Momoko Kawakami, 'Global Value Chains in the Electronics Industry: Was the Crisis a Window of Opportunity for Developing Countries?' (2010), 5417 The World Bank, Policy Research Working Paper, 4-5.

30 Jenny Chan, Ngai Pun and Mark Selden, 'Apple, Foxconn and China's New Working Class', in Richard P Appelbaum and Nelson Lichtenstein, (eds), Achieving Workers' Rights in the Global Economy (Cornell University Press, 2016), 173.

31 For an in-depth analysis of the companies involved in the supply chain and their roles, see Electronics Watch (WEED), The ICT Sector in the Spotlight, Leverage of Public Procurement Decisions on Working Conditions in the Supply Chain, 2014, http://electronicswatch.org/the-ict-sector-in-the-spotlight_723519.pdf (accessed 1 April 2017). In particular, in relation to Apple, a New York Times study of the iPhone and iPad's supply chain in 2012 revealed the following distribution of the production: the software is produced in the USA, whilst semiconductors are produced in countries such as Germany and Taiwan, memory boards, display panels and circuits in Japan, data ships in Europe and hundreds of components are assembled in China. Metals are extracted, smelted and refined in countries of Africa and Asia; Charles Duhigg and Keith Bradsher, 'How the US Lost Out on iPhone Work', New York Times, 12 January 2012.

32 ILO, The impact of procurement practices in the electronics sector on labour rights and temporary and other forms of employment. WP 313. International Labour Office, Geneva, 2016.

33 Jenny Chan and C Ho (WEED - World Economy, Ecology, and Development - and SACOM -Students and Scholars against Corporate Misbehavior), The Dark Side of Cyberspace. Inside the Sweatshops of China's Hardware Production (2008), http://electronicswatch.org/the-dark-side-of-cyberspace_3378.pdf (accessed 1 April 2017).

34 ILO, note 26. 
workforce in some areas of China, Malaysia, Hungary and Mexico during peak production periods are temporary contract workers. ${ }^{35}$ The use of temporary and contracted labour limits job security, restricts opportunities for advancement, and often prevents employees from accruing benefits that would be available through permanent employment. ${ }^{36}$ In China and the Philippines, certain parts of the industry have staffed their operations with student labour, interns and 'on the job trainees', who in many instances are not free to choose their employment. ${ }^{37}$ Workers on short contracts and students are generally excluded from work benefits and full wages that would apply to permanent employees. ${ }^{38}$ Precarious terms of employment, lack of job security and fluctuations in work demand makes staff turnover high in factories, perpetuating the lack of access to employment benefits. ${ }^{39}$ One of the main issues in the industry is the lack of adequate wages, which in most cases is less than a living wage. ${ }^{40}$ Routine overtime - including forced overtime - and excessive working hours are common, as are pressures on workers' time due to peaks of demand or shorter time-leads. ${ }^{41}$ Discrimination not only happens between migrant and local employees, or contracted and permanent ones, but also along gender lines. Often women are favoured as employees because they attract lower wages. ${ }^{42}$ Unionization and collective bargaining is very low in the industry. In some producing countries this is because protective legislation is not implemented, whilst in others freedom of association is restricted by law. Factories also put barriers to association and representation and participation in strikes or other collective worker organizing activities may lead to punitive action from the employer. ${ }^{43}$ Undermining trade unions is a key factor of the flexibility of the supply chain.

Migrant workers constitute an additional dimension to flexible workforces. Migrant workers may be temporary agency workers but they also may be core employees. These workers are particularly vulnerable. They are exposed to exploitation by recruiters, tend

\footnotetext{
35 Ricarda McFalls, The impact of procurement practices in the electronics sector on labour rights and temporary and other forms of employment, International Labour Office, Geneva, 2016.

36 A Ferus-Comelo and P Pöyhönen. (Finnwatch, Cividep and SOMO), Phony Equality: Labour standards of mobile phone manufacturers in India, 2011, http://electronicswatch.org/phony-equality_3565.pdf (accessed 1 April 2017).

37 Danwatch, Servants of Servers, Rights Violations and Forced Labour in the Supply Chain of ICT Equipment in European Universities, 2015, https://www.danwatch.dk/wp-content/uploads/2015/10/Servants-of-servers.-DanwatchInvestigation.pdf (accessed 1 April 2017); Electronics Watch, Regional Risk Assessment: Semiconductor and Electronics Industry, Philippines, December 2016 and Electronics Watch, Regional Risk Assessment: Semiconductor and Electronics Industry, China, October 2016, http://electronicswatch.org/en/publications-by-electronics-watch_1633 (accessed 25 September 2017).

38 Chan and Ho, note 33; Danwatch, note 37; China Labor Watch, An Investigation of Eight Samsung Factories in China: Is Samsung Infringing upon Apple's Patent to Bully Workers?, 2012, http://www.chinalaborwatch.org/report/64 (accessed 1 April 2017).

39 Kakuli and Schipper (SOMO and Swedwatch and Global Standards), Out of Focus: Labour Rights in Vietnam's Digital Camera Factories, 2011, http://electronicswatch.org/out-of-focus_3571.pdf (accessed 1 April 2017); China Labour Watch, note 38.

40 Ferus-Comelo and Pöyhönen, note 36; Kakuli and Schipper, note 39; Chan and Ho, note 33.

41 China Labor Watch, note 38.

42 Kakuli and Schipper, note 39; Chan and Ho, note 33. A growing share of those employed in global supply chains are women, particularly as a percentage of supply chain workers in emerging economies, ILO Non-Standard Forms, note 22 .

43 Annita Chan, 'Organizing Wal-Mart in China: Two Steps Forward, One Step Back for China's Unions' (2007) 16 New Labor Forum 86-96; Chan and Ho, note 33; Ferus-Comelo and Pöyhönen, note 36.
} 
to be more willing to tolerate exploitative practices in workplaces and are less inclined or have less opportunities to be organized in trade unions. ${ }^{44}$ The fact that they are newly arrived, may not know the language, do not know their rights and do not have a social network of support means that they are less likely to assert their rights and oppose abusive labour practices. For example, in 2014 the organization Verite uncovered that nearly a third of migrant workers in Malaysia's electronics sector were in a situation of forced labour, trapped by burdensome debt owed to recruitment agents and deprived of accesses to their identity documents. ${ }^{45}$

Working conditions in the factories tend to be poor. Strict rules for employees apply, with inadequate time for rest or meal breaks and punitive sanctions for breaches of these rules reported. ${ }^{46}$ Several parts of the manufacturing process involve exposure to hazards, especially chemicals, on many occasions without the right protective equipment. ${ }^{47}$ Living conditions are also an important concern in the industry. While some workers have to commute long distances, others are provided accommodation - or required to live - in factory premises. Workers have been found to live in poor-quality, overcrowded accommodation in order to reduce their own expenditure. ${ }^{48}$ Factory-provided accommodation may also be overcrowded and lacking adequate standards of habitability. ${ }^{49}$

The structural organization of the electronics supply chain means that the brands or main retailers that sell their products to public authorities are typically not in a direct contractual relationship with the employees of their suppliers or with subcontractors, and may, willingly or unwillingly, be oblivious to the human rights abuses impacting the workers who produce the goods they sell. This should not be a deterrent for companies to take responsibility over the wellbeing of those workers, especially as companies embrace the UNGPs, which extend the responsibility to protect human rights through the whole business activities and partnerships of a company. Even if electronics brands - and the industry as a whole ${ }^{50}$ - have made significant efforts in the past years to assume corporate social responsibilities, product suppliers have not assumed equivalent responsibilities in relation to their subcontractors and manufacturers.

Cascading social commitments tends to be easier said than done. Also, as Berliner and his co-authors assert, brands are often sending mixed signals to suppliers by asking them to both compete on price and simultaneously raise labour standards. ${ }^{51}$ This is where a new approach is taking off: enlisting public (government) buyers into this responsibility as well. The next section explores this relationship between the government buyer and

\footnotetext{
44 Tim Pringle, 'Reflections on Labor in China: From a Moment to a Movement' (2013) 112 South Atlantic Quarterly; Chan and Ho, note 33; China Labor Watch, note 38.

45 Verite, Forced Labor in the Production of Electronic Goods in Malaysia. A Comprehensive Study of Scope and Characteristics, 2014, http://www.verite.org/research/electronicsmalaysia (accessed 1 April 2017).

46 Chan and Ho, note 33.

47 Kakuli and Schipper, note 39.

48 Ferus-Comelo and Pöyhönen, note 36.

49 Ngai Pun and Jenny Chan, 'Global Capital, the State, and Chinese Workers: The Foxconn Experience' (2012) 38 Modern China, 383.

50 Together with individual company initiatives, industry associations such as the Electronic Industry Citizenship Coalition (EICC) are making efforts to raise the social and environmental standards in the supply chain, see www. eiccoalition.org.

51 Daniel Berliner, Anne Regan Greenleaf, Milli Lake, Margaret Levi and Jennifer Noveck, Labor Standards in International Supply Chains. Aligning Rights and Incentives (Edward Elgar, 2015), 22.
} 
the larger electronics brands as sellers, and how Electronics Watch is attempting to bring together these actors, interests and responsibilities.

\section{Improving the Electronics Supply Chain for Workers through Public Procurement}

Involving those who use public funds to purchase goods into ethical buying decision making and processes is not new. In the United States, university and college students have led the way for years, from boycotting commercial relationships with apartheid South Africa, demanding the cut of links with companies producing in Burma, and lobbying administrators to rejecting sweatshop apparel in university merchandise. In the early 2000s, the Worker Right's Consortium (WRC) was one of the first organizations to link the buying power of universities to improving working conditions in faraway factories in the garment sector (albeit not technically regarding procurement, but university licensing).

Today, the WRC supports 175 educational institutions in the USA. ${ }^{52}$ This is focused on the garment sector, as are most existing initiatives. Individual public bodies in the USA and Europe have also attempt to pursue ethical purchasing over the years; however, most of the existing initiatives have been very localized, with limited capacity to transform the sector. ${ }^{53}$ Therefore, the experience so far is rather limited.

Based in Europe, Electronics Watch's aim is to transform supply chain relationships through the power of public buying, by employing innovative premises and tools. ${ }^{54}$

\section{A. Leverage and Collaboration: The Affiliation Model}

Electronic goods comprise a significant portion of public purchases. ${ }^{55}$ These goods are often high-value items and are procured in high volumes. Equally, contracts between public buyers and suppliers tend to be relatively long compared with those between suppliers themselves. Electronics Watch takes advantage of this by basing its model on the leverage public buyers have with regard to their suppliers and a durable relationship that allows for a sustained engagement between the parties. It is based on an affiliation model. Public buyers affiliate, paying an annual fee proportional to their volume of annual ICT hardware spending, to access Electronics Watch tools and instruments.

52 Denis G. Arnold and Laura P. Hartman, 'Worker Rights and Low Wage Industrialization: How to Avoid Sweatshops' (2006) 28 Human Rights Quarterly 676-700.

53 See, for example, Landmark Project, Success Stories in Socially Responsible Public Procurement. Using Public Spending to Drive Improvements for Workers in Global Supply Chains, 2014, available at http://www.landmarkproject.eu/fileadmin/files/en/LANDMARK_Success_Stories_2014_-_eng.pdf (accessed 1 December 2017).

54 Electronics Watch is the result of European Commission funded project from 2013 to 2015, led by the Spanish nongovernmental organization, SETEM. Other project partners included Centrum CSR (Poland), DanWatch (Denmark), People and Planet (UK), SOMO (Netherlands), Südwind (Austria), and WEED (Germany). This consortium conducted research on the electronics industry, developed model contract clauses, a code of labour standards, and other procurement tools consistent with the EU procurement directive, developed dialogue and educational forums with public sector buyers in their own regions, recruited 70 advisors and the first affiliates to Electronics Watch. The project ended in 2015 and Electronics Watch was incorporated under Dutch law and started conducting activities in its own right.

55 There are no up-to-date figures on the amount of ICT hardware purchasing, but in 2002 it was estimated that by 2007 ICT procurement in the EU would amount to 94 billion Euros (European Union, Guidelines for Public Procurement of ICT Goods and Services, 2012, 4, http://cordis.europa.eu/fp7/ict/ssai/docs/study-action23/d2finalreport-29feb2012.pdf (accessed 1 April 2017). 
The instruments are, principally, a Code of Labour Practices, a set of model contract clauses (Contract Conditions), Contractor Guidance, and most importantly, a network of local monitors that develop factory monitoring and on-the-ground worker engagement.

The Electronics Watch model capitalizes on the power of collaboration among public buyers. When public buyers consolidate their buying efforts, they are capable of negotiating bigger contracts - through, for example, framework agreements, and therefore have greater leverage over contractors. This way, public buyers may have more direct economic power over their contracted suppliers. This power of collaboration and engagement builds on a confluence of common practices in domestic public buying, such as purchasing consortia, and international practices of multi-stakeholder interaction, which are common in corporate social responsibility and business and human rights initiatives. ${ }^{56}$ The ultimate goal of this model is to transform supply chains through creating sufficient market demand via public purchasing practices for brands to engage in supply chain improvement.

Similar initiatives exist in the United States, where as described above the influence of large purchasers has been relied upon before. As mentioned previously, the WRC is an independent monitoring organization that works with colleges and universities in the United States to support them in their apparel-related licensing with the aim to avoid sweatshop labour and defend workers' rights in the supply chain of apparel. ${ }^{57}$ A notable initiative is the Sweatfree Purchasing Consortium (SPC), established in 2010. It is a membership organization of public entities; it has been created by these public entities to manage procurement more efficiently and with less risk in human rights terms. It seeks to avoid sweatshop practices in the supply chain of the products - mainly garments - its members buy. ${ }^{58}$ The initiative is equally based upon recognition of the economic influence of public procurement as a means of influencing working conditions in the supply chain. However, its support for buyers is more policy based than Electronics Watch. The SPC serves as a coordinating body and resource centre, providing its members with a model purchasing agreement. Electronics Watch, by contrast, is a monitoring organization, providing tools for engagement between workers, suppliers and public buyers.

By including public buyers as agents of change, these organizations are seeking to empower them to take responsibility over their own contribution to human rights abuses in the supply chain, and challenging the assumptions that supply chains are too complex for consumers - public buyers - to understand, influence and transform. It also confronts the common reality of responsibility for improving worker human rights, beyond being passed down the chain in a way that cannot be monitored or enforced, or solutions being outsourced by simply commissioning auditing reports. Public sector organizations tend to value social responsibility and sustainability and many have ethical policies in place already. Taking some responsibility for the human rights of the workers who produce the electronics products they buy is a new step.

\footnotetext{
56 Many of these multi-stakeholder initiatives include non-governmental organizations, business and governments. Electronics Watch does not include businesses.

57 See http://www.workersrights.org/.

58 For further information, see the Consortium's website at http://www.sweatfree.org/about_us.
} 
The model relies on leverage: leverage from the public buyer to its contracted supplier (retailer or directly the brand) and the contracted supplier towards its own subcontractor. Leverage, in the context of corporate human rights violations, is defined by the UNGPs when articulating the corporate responsibility to respect, in particular when listing what companies should do to prevent and mitigate human rights abuses. ${ }^{59}$ According to the Commentary to UNGP 19, leverage can be considered 'to exist where the enterprise has the ability to affect change in the wrongful practices of an entity that causes the harm'. ${ }^{60}$ As Lukas has asserted, leverage is a measure 'to assess what a company can do to support human rights or end a human rights violation of an actor with regard to a certain power proximity and relationship influence'. ${ }^{61}$ Applying this same concept to public buyers implies considering what they can do to demand transparency from their suppliers and influence their behaviour so in turn they do the same to their own suppliers. Leverage in the context of business and human rights appears to have been originally directed to the private sector, such that business would exercise leverage towards companies directly linked to its operations, products or services by its business relationship. In fact, the UNGPs do not refer to leverage when developing the state duty to protect.

Nevertheless, there is a strong argument to consider that the demand to exercise leverage over those who they have direct business relationships also applies to public authorities. In exercising it, they contribute to the fulfilment of their own duties with regard to human rights protection. Electronics Watch envisages that public buyers would be able to exercise leverage, by pooling resources designed to obtain reliable intelligence about working conditions in the industry, engage with suppliers and ultimately create effective market demand for decent working conditions in their ICT hardware supply chains. Public buyers' leverage is in turn used to promote contractor's leverage from the premise that leverage is not static for anyone, 'It is a capacity that must be exercised, and, through this exercise, strengthened'. ${ }^{2}$

The specific obligations assumed by Electronics Watch affiliates are: to pay an annual fee, which is proportional to their ICT spending; to incorporate the Electronics Watch

59 UNGP 19: 'In order to prevent and mitigate adverse human rights impacts, business enterprises should integrate the findings from their impact assessments across relevant internal functions and processes, and take appropriate action: [...] (b) Appropriate action will vary according to: (i) Whether the business enterprise causes or contributes to an adverse impact, or whether it is involved solely because the impact is directly linked to its operations, products or services by a business relationship; (ii) The extent of its leverage in addressing the adverse impact."

60 According to the Commentary of UNGP 19, 'Leverage may reflect one or more of a number of factors, such as: (a) whether there is a degree of direct control between the enterprise and the supply chain entity; (b) the terms of contract between the enterprise and supply chain entity; (c) the proportion of business the enterprise represents for the supply chain entity; (d) the ability of the enterprise to incentivize the supply chain entity for improved human rights performance in terms of future business, reputational advantage, capacity-building assistance etc.; (e) the reputational benefits for the supply chain entity of working with the enterprise, and the reputational harm of that relationship being withdrawn; (f) the ability of the enterprise to engage other enterprises that work with the supply chain entity in incentivizing improved human rights performance; $(\mathrm{g})$ the ability of the enterprise to engage local or central government in requiring improved human rights performance by the supply chain entity through implementation of regulations, monitoring, sanctions, etc.'

61 Karin Lukas, 'Human Rights in the Supply Chain: Influence and Accountability' in Radu Mares (ed), The UN Guiding Principles on Business and Human Rights: Foundations and Implementations (Martinus Nijhoff Publishers, 2012).

62 Electronics Watch, Contractor Guidance for Electronics Watch Contract Conditions, version 1.1, September 2017, available at http://electronicswatch.org/nl/the-electronics-watch-contractor-guidance_2525835 (accessed 25 September 2017). 
Contract Conditions, or equivalent, into their ICT hardware contracts with new suppliers or when contracts are renewed; and to nominate a point of contact in their organization. These instruments are analysed below.

\section{B. The Standards: Code of Labour Practices}

The Electronics Watch Code of Labour Practices (the Code) ${ }^{63}$ reflects international legal standards, as do most civil society codes. It has been drafted taking into account the specificities of the industry. ${ }^{64}$ It contains a series of standards and sub-standards, based on the fact that many international labour regulations lack the detail and specificity to make standards. For each standard the Code contains a set of sub-standards that describes specific practices that are prohibited. ${ }^{65}$ Electronic Watch guarantees that standards in the Code are general enough that they capture the widest possible range of human rights abuses but also specific enough to be easily interpreted and enforced.

In order to be compliant, electronics goods manufactured in the supply chain of the companies that are bound by the Code (in a manner that will be explained in the next section) must be produced under conditions that comply with all the standards contained in the Code. This means, according to the Code itself: (a) where the standards relate to the rights and conditions of workers, the workers must benefit from all the rights and conditions listed, and (b) where the standards relate to workplaces, the goods must be produced in workplaces that meet all of the standards. ${ }^{66}$

Specifically, with regard to its content, the Code features provisions related to domestic law, international labour law and a clause dealing with the potential contradiction between the two. Firstly, contractors must comply with domestic labour law in the countries where they produce goods or services and must ensure that their subcontractors do the same. Contractors must also comply with the international labour standards and sub-standards listed, which refer to the ILO Core Conventions (ILO Nos 29, 105, 87, 98, 100, 111, 138 and 182) as well as to ILO Conventions Nos 1, 95, 102, 115, 131, 135, 155, 158 and 170, ILO Recommendations Nos 35 and 143, Article 34 of the ILO Tripartite Declaration of Principles concerning Multinational Enterprises and Social Policy and Article 32 of the United Nations Convention on Rights of the Child. The core international labour standards refer to: free choice of employment; freedom of association and the right to collective bargaining; no discrimination in employment; and no exploitative child labour. Additional international labour standards refer to: no excessive working hours; safe and healthy working conditions; and no abusive termination of employment and living wages.

In the case of divergence between international and domestic standards, the Code establishes that it would be the standard which provides greater protection to the worker

63 Electronics Watch Code of Labour Practices, available at http://electronicswatch.org/code-of-labourstandards_2460399.pdf (accessed 1 April 2017).

64 The Code was developed by a Working Group including representatives from numerous human rights and labour rights organizations, academics and practitioners. The author was part of this group.

65 These sub-standards condense the more than 300 compliance points developed by the ILO Better Work Programme into a more manageable number of compliance points that serve as indicators of broad compliance.

66 Electronics Watch Code of Labour Practices, Introduction, note 63. The Code also defines the workers involved in the production of goods for its purposes as any worker who has 'any involvement, however slight, in the assembly of the Goods or the production of the electrical components from which the Goods are assembled'. 
that should prevail. A particularly problematic issue when drafting the Code appeared regarding the issue of freedom of association, which is legally (as well as de facto) restricted in several producing countries and which would directly provoke a divergence of standards between applicable national law and international standards which afford further protection to the worker. While the Code is clear that it does not require a contractor or subcontractor to violate domestic law in a country of production, it also demands contractors to honour international standards. Therefore, particularly with regard to freedom of association the Code asks contractors to permit all activities related to freedom of association that are not prohibited by domestic law, as well as avoid practices that violate international standards unless a practice is mandated by domestic law. ${ }^{67}$

As the Code was developed, another issue that arose was how to calculate living wage, which took up a lot of time of the Model Working Group. Beyond the right of workers to receive their legal wages, goods must be produced by workers who receive a living wage. ${ }^{68}$ A living wage is a key concept when addressing workers' rights in the supply chain in general, and in the electronics industry, in particular, where, as described in the first section, overtime is inherent to the working conditions, given that basic salaries do not cover the basic living needs of workers and their families. There have been numerous attempts to define and calculate a living wage. ${ }^{69}$ The Electronics Watch Code provides its own: a 'living wage' means a 'take home' or 'net' wage (excluding any taxes, bonuses, allowances, or overtime wages) earned during a country's legal maximum work-week (not exceeding 48 hours), which is sufficient to pay for the basic needs (housing, energy, nutrition, clothing, health care, education, potable water, childcare and transportation) of a family of four people, and includes an additional $10 \%$ of the cost of basic needs as discretionary income. ${ }^{70}$

\section{Contract Performance Conditions: An Effective Due Diligence Model}

As previously mentioned, one of the obligations assumed by affiliates is to incorporate a model contract clause, the 'Contract Conditions', or equivalent, which establishes contractor responsibility. Contractor responsibility is based on due diligence. ${ }^{71}$ One of the main concerns during the drafting of the Contract Conditions was whether it meshed with the existing EU procurement regulation. Traditionally, public contracting authorities have been much freer to impose environmental and social conditions when negotiating conditions governing how the contract with the supplier must be performed, while they are relatively restricted from imposing such conditions in the other phases of procurement (e.g., technical specifications and award criteria). Since contract performance conditions apply after the contract has been awarded they do not impact the

67 Ibid, Standard 3.

68 Electronics Watch Code of Labour Standards, Standard 12, note 63.

69 See, for example, the work of the Global Living Wage Coalition to define and design a calculation methodology: http://www.isealalliance.org/our-work/improving-effectiveness/global-living-wage-coalition (accessed 1 April 2017).

70 Electronics Watch Code of Labour Practices, Standard 12, note 63.

71 Martin-Ortega, Outhwaite and Rook, note 18. The Electronics Watch Model Working Group discussed several options to include contractor obligation in the supply chain during the drafting process of the Contract Clauses, including cascading clauses that needed to be inserted in every contract at every level of the supply chain. 
assessment of tenders and therefore are less likely to cause problems related to the principles of equal treatment, non-discrimination and transparency.

Contract performance conditions must relate to the execution of the contract, rather than forming the basis of the award, and it is not necessary for tenderers to demonstrate compliance prior to the award of the contract. EU regulations expressly state that those conditions may include 'economic, innovation-related, environmental, social or employment-related considerations' (Article 70, Directive 2014/24/EU), as long as they relate to the subject matter of the contract. ${ }^{72}$ Thus the Contract Clauses take advantage of the wider and more permissive rule that applies to contract performance conditions over those applicable at earlier stages of the procurement process. Equally, contract conditions apply to the duration of the contract, allowing for more sustained engagement between the contracting authority and the contractor.

A model based on the introduction of contract performance conditions in public buyerscontractor agreements specifically stays away from two popular models in corporate social responsibility: the multi-stakeholder approach and the certification scheme approach. The multi-stakeholder approach requires the involvement of states, civil society and industry representatives. Whilst these models are being used in several sectors, notably the apparel sector, and they have their supporters, the multi-stakeholder path has not been straightforward. ${ }^{73}$ Certification schemes can form part of these multi-stakeholder initiatives - such as the Kimberley Process for certification of diamonds - or led by civil society organizations or non-profit enterprises, which demand the compliance of companies with a set of standards. An example in the electronics industry is the Green Electronics Council and TCO Development, which certify electronics products based on a series of sustainability criteria. ${ }^{74}$ On other occasions non-governmental organizations partner directly with corporations to guide their processes and monitoring of standards in the production process (see section below for monitoring). There is also a prolific practice of corporations and industry associations themselves defining standards and embedding them in the supply chain legal framework by incorporating their own codes of conduct into contracts with suppliers and subcontractors. ${ }^{75}$ An example of this is the Electronics Industry Citizenship Coalition (EICC), recently re-branded as the Responsible Business Alliance.

The Electronics Watch model involves a network of affiliated public sector buyers who use the organization's structure to create monitoring and compliance capacity. Companies

\footnotetext{
72 Article 70 establishes that contract performance conditions are permitted where related to the subject matter of the contract within the broader meaning established in article 67(3), which defines what subject matter is in relation to award criteria: 'Award criteria shall be considered to be linked to the subject-matter of the public contract where they relate to the works, supplies or services to be provided under that contract in any respect and at any stage of their life cycle'.

73 Dorothee Baumann-Pauly, Justine Nolan, Auret van Heerden and Michael Samway, 'Industry-Specific MultiStakeholder Initiatives that Govern Corporate Human Rights Standards - Legitimacy Assessments of the Fair Labor Association and the Global Network Initiative' (2015) 12 University of New South Wales Faculty of Law Legal Studies Research Paper Series; Justine Nolan, 'Refining the Rules of the Game: The Corporate Responsibility to Respect Human Rights' (2014) Utrecht Journal of International and European Law, 30-78; Scott Jerbi, 'Assessing the Roles of Multi-Stakeholder Initiatives in Advancing the Business and Human Rights Agenda' (2013) 94 International Review of the Red Cross, 887; Atabongawung Tamo, 'New Thinking on Transnational Corporations and Human Rights: Towards a Multi-Stakeholder Approach' (2016) 34 Netherlands Quarterly of Human Rights, 147-73.

74 See http://greenelectronicscouncil.org/sustainable-solutions/epeat/ and http://tcodevelopment.com/sustainable-it/.

75 Anna Becks, Enforcing Corporate Social Responsibility Codes (Oxford: Hart, 2015).
} 
commit to legally binding obligations with regard to the rights of workers. These obligations enter the supply chain through the introduction of the Contract Conditions as part of the contract performance conditions in the contract between a public buyer and its direct supplier, the brand or the retailer. Specifically, distancing itself from industry involvement means that 'Electronics Watch does not certify or rate products, factories, or companies for compliance with labour rights and safety standards' ${ }^{76}$ No company can claim complete compliance in its supply chain, '[t]hus, the goal of any one contract for electronics products is to detect breaches and help improve conditions for workers who make the products', rather than provide a company or its products with a stamp of approval.

A public procurement model that involves contractor due diligence is consistent with the current tendency in the field of business and human rights, an approach which assumes an active role on the part of businesses to manage adverse human rights impacts beyond considering them mere business risks. ${ }^{77}$ As per the UNGPs, corporate human rights due diligence demands of corporations to have processes to identify, prevent, mitigate and account for how they address their impact on human rights. ${ }^{78}$

The Contract Conditions are designed under this model and consistent with the UNGPs, and the OECD Guidelines on Multinational Enterprises. The Contract Conditions require the contractor to perform due diligence to 'identify, prevent and mitigate risk of breach, remedy actual breaches, and compensate workers affected by the breaches'. ${ }^{79}$ It is arguable that they further contribute to the development of corporate human rights due diligence by providing sectoral specific rules. Furthermore, they go one step ahead by demanding 'effective and accountable due diligence' ${ }^{80}$ Contractors are required to 'achieve outcomes within [their] control, that is, outcomes [they] can achieve without intervention by another actor. If a contractor does not achieve this specific outcome, and they are not within the contractor's control, the contractor must comply with its contractual obligations by exercising and demonstrating effective due diligence' [added emphasis]. ${ }^{81}$ The compliance with these obligations is based on a model of 'comply or explain', which allows to aim for behaviour change and systemic improvements while still allowing flexibility and evolution. ${ }^{82}$ However, this is also a sort of due diligence plus as it moves away from the obligation of process established by the international soft-law instruments mentioned and some of the current national legislation

\footnotetext{
76 Electronics Watch Contract Conditions, http://electronicswatch.org/en/the-electronics-watch-contract-conditions_ 2459984 (accessed 1 April 2017).

77 Robert McCorquodale, 'Corporate Social Responsibility and International Human Rights Law' (2009) 87 Journal of Business Ethics 392; Olga Martin-Ortega, 'Human Rights Due Diligence for Corporations: form Voluntary Standards to Hard Law at Last?' (2014) 32 Netherlands Quarterly of Human Rights 49-50; Robert McCorquodale, Lise Smit, Stuart Neely and Robin Brooks, 'Human Rights Due Diligence in Law and Practice: Good Practices and Challenges for Business Enterprises' (2017) 2 Business and Human Rights Journal 198.

78 UNGP 15. The OECD Guidelines on Multinational Corporations follow the UNGPs in the definition of corporate human rights due diligence.

79 Electronics Watch Contract Conditions, note 76.

80 Electronics Watch, Contractor Guidance note 62. The Contractor Guidance has been developed in consultation with over 25 organizations, including affiliates, reseller and brand companies as well as human rights and health and safety experts and labour rights organizations. They have been endorsed by civil society organizations and public buyers and academics including Radu Mares and Robert Stumberg.

81 Electronics Watch, Contractor Guidance note 62, p 11.

82 Radu Mares, Endorsement of Electronics Watch Contract Clauses, available at http://electronicswatch.org/en/theelectronics-watch-contractor-guidance_2525835 (accessed 25 September 2017).
} 
that establishes due diligence-related obligations (transparency and reporting), such as Section 1502 of the 2010 US Dodd Frank Act and the 2015 UK Modern Slavery Act, to an obligation of result. This is in line with new normative developments, mainly represented by the 2017 French Duty of Vigilance Law, which focus on the effectiveness of due diligence measures and attach consequences to the lack of adoption of such measures or their inadequacy to prevent human rights violations. ${ }^{83}$

Relying on a model of due diligence provides the necessary flexibility to allow a progressive process of responsibility and supplier engagement, from disclosure to establishing a clear obligation of result (effective due diligence measured against detailed benchmarks). This goes beyond current corporate human rights due diligence practice. The challenge is to articulate this flexibility in practice whilst at the same time being able to define specifically how the compliance with the obligation to exercise effective due diligence is measured.

The Contract Conditions rely on the concept of leverage, discussed in the previous section. The contractor needs to exercise leverage to perform its responsibilities to achieve compliance with the Code of Labour Practices. Flexibility is also needed based on the recognition that the contractor in the public procurement agreement may be a brand, with relatively more control over the supply chain, or a reseller with less leverage. Both types of companies are capable of complying with the Electronics Watch Contract Conditions. With regard to how to measure due diligence compliance, the Contract Conditions establish that contractors are responsible for due diligence to ensure socially responsible trading conditions in the supply chain: that is, pricing and delivery terms that ensure compliance with labour rights and safety standards is feasible. ${ }^{84}$ Therefore, the Contract Conditions contribute to operationalize the broad concept of corporate human rights due diligence and provide it with specific meaning in the context of the industry. This is an important practice that so far has been developed in very few sectors. ${ }^{85}$

The specific obligations acquired by the contractors in their exercise of due diligence have been further defined in the Contractor Guidance, which was published in 2017. The Contractor Guidance contains eleven outcomes that should be achieved by the contractors in specific timeframes. These are outcomes regarding: factories and products transparency, materials transparency, compliance data transparency, transparency regarding trading conditions, factory cooperation and factory compliance with Electronics Watch Code Labour Practices.

Where Electronics Watch identifies unsatisfactory performance, e.g., failure to exercise leverage to address breaches of the Code, it can engage with contractors, on behalf of affiliates, to achieve compliance. As a last resort, affiliates can decide to use contractual sanctions to obtain remedy, as is analysed in the next section. The Contract

\footnotetext{
83 See in particular, Sandra Cossart, Jerome Chaplier and Tiphaine Beau de Lomenie, 'The French Law on Duty of Care: A Historic Step Towards Making Globalization Work for All' (2017), 2 Business and Human Rights Journal, 317-23.

84 See publicly available information on the Electronics Watch website: http://electronicswatch.org/en/theelectronics-watch-contract-conditions_2459984 (accessed 1 April 2017).

85 The OECD has provided detailed guidance on how to articulate corporate due diligence in other sections of the supply chain, e.g., with regard to the extraction of tin, tungsten, tantalum and gold, but so far this remains one of the most pressing challenges in the development of standards and practice regarding the corporate responsibility to respect human rights. See http://www.oecd.org/corporate/mne/mining.htm (accessed 1 April 2017).
} 
Conditions have started to be inserted in new procurement contracts. The first one was the UK Higher Education and National Apple Equipment and Services Framework Agreement, in April 2016. ${ }^{86}$ Following this agreement several UK universities have included the Contract Conditions within their individual contracts with suppliers within this Framework Agreement. As of August 2017, seven contracts have included the Contract Clauses across Europe. ${ }^{87}$ This has allowed the engagement with contractors but also called the attention of brands. In addition, four brands are currently engaged in factory compliance. ${ }^{88}$

\section{Monitoring Supply Chains: A New Model of Worker-Driven Monitoring}

To verify compliance, Electronics Watch monitors factories that contractors have disclosed in accordance with their obligations under the Contract Conditions. Having access to reliable monitoring of their supply chain is one of the main values added for public buyers affiliated to Electronics Watch. However, at the same time this is one of the most challenging elements of the model: how can contractors and public contracting agencies guarantee reliable monitoring that provides a set of verifiable data to act upon? Public buyers have not traditionally considered the monitoring of their supply chain as part of their responsibility and it is highly likely that they do not have the resources to undertake this role directly.

In 2003, Michael Santoro warned of the limitations of compliance-oriented human rights policies, including codes of conducts and monitoring. ${ }^{89}$ As he asserted, while codes and monitoring can lead a company to determine how well or poorly its manufacturing facilities are in terms of human rights, they cannot per se "fix the problems they uncover'. ${ }^{90}$ Since, and more significantly since the Rana Plaza disaster, monitoring compliance through social auditing has been discredited as being questionable in terms of independence and effectiveness, unable to bring to light some of the most flagrant violations of workers' rights. ${ }^{91}$ Furthermore, as Lukas notes, audits have been mostly concerned with health and safety issues and paid less attention to wages, overtime and trade union rights, which are critical for the improvement of working conditions. ${ }^{92}$ In fact, a salient criticism over current monitoring and social auditing is that they rarely include workers and trade unions as part of their processes. Monitoring has mostly been led by corporations or third parties hired from auditing

\footnotetext{
86 See http://electronicswatch.org/the-uk-higher-education-and-national-apple-equipment-and-services-frameworkagreement_2455571.pdf. This Framework Agreement had been signed with four suppliers, not including Apple.

87 Electronics Watch Impact and Project Results at a Glance, 1 August 2017 (on file with the author).

88 Ibid.

89 Michael Santoro, 'Beyond Codes of Conduct and Monitoring: An Organizational Integrity Approach to Global Labor Practices' (2003), 25 Human Rights Quarterly 407-24.

90 Ibid. The author provides an interesting simile: 'while codes of conduct and monitoring systems can uncover human rights problems, they are not, in and of themselves, solutions to these problems. Just as financial accounting can't generate profits, monitoring factories can't generate good conditions. In each case, the process can only help us to determine whether or not financial or social objectives are being met.'

91 Genevieve Le Baron, Jane Lister and Peter Dauvergne, 'Governing Global Supply Chain Sustainability through the Ethical Audit Regime' (2017), 14 Globalizations 958-75.

92 Lukas, note 61,161 . As the author says, improvements suggested in these kind of audits - such as better lighting, ventilation, etc. - 'relate to processes upgrading as they also increase productivity by a more "efficient" use of the "human resource",
} 
firms to industry association and industry-backed initiatives, to ensure compliance of voluntary standards. These processes have tended to 'deliver for management and corporations, but not for the workers they claim to benefit' ${ }^{93}$

Over a decade ago some companies claimed to have adopted a 'beyond monitoring' approach, based on capacity building and dialogue with suppliers rather than top-down control to ensure compliance. ${ }^{94}$ However, it is arguable that no significant change has been brought to workers in global supply chains. Alternative systems of monitoring and auditing of factories and labour conditions need to be found, especially initiatives that place workers at the heart of the process, rather than mechanical compliance with company or industry standards.

Electronics Watch has explicitly avoided the social auditing model and steered away from the limitations of this kind of externally led monitoring by relying on a network of local monitoring organizations to develop 'worker-driven monitoring'. ${ }^{95}$ While external third party auditors tend to move quickly in and out of factories and only get partial pictures of the reality, local workers' rights associations and civil society organizations understand the reality of the country, industry and factory. They have the rapport and trust to provide significant engagement with workers. This type of monitoring has at its core the goal of strengthening workers' voices so that they are able to report on and address safety and labour issues on their own or in collaboration with the companies, rather than having externally based, and/or imposed processes of monitoring and supply chain reform. The premise is that workers are the best monitors as they are on site all day, every day. They know the process and problems of normal operations; they have ideas for resolving safety and labour rights problems; and they can verify whether corrections are implemented and actually work. In this monitoring model, workers are active; they bring attention to issues and can set in motion investigations and remedial activities. $^{96}$

A significant challenge to the implementation of the Electronics Watch model is therefore establishing this network of local monitors, who are qualified local civil society organizations, able to undertake continuous intelligence gathering and at the same time maintain trusted relationships with workers. ${ }^{97}$ A relevant criterion for the selection, beyond their expertise and independence from the industry, should be that they have ongoing relationships of trust with workers in electronics factories. This is important as they must be able to meet with them in safe settings where workers can share information

\footnotetext{
93 AFL-CIO, Responsibility Outsourced: Social Audits, Workplace Certification, and Twenty Years of Failure to Protect Worker Rights, 2013, http://www.aflcio.org/content/download/77061/1902391/CSReport.pdf (accessed 1 April 2017).

94 Business for Social Responsibility, Beyond Monitoring: A New Vision for Sustainable Supply Chains, 2007, https:// www.bsr.org/en/our-insights/report-view/beyond-monitoring-a-new-vision-for-sustainable-supply-chain (accessed 1 April 2017); Richard Locke, Q Fei and A Brause, 'Does Monitoring Improve Labor Standards? Lessons from Nike' (2007), 61 ILRREVIEW 3-33.

95 Electronics Watch Worker Driven Monitoring, http://electronicswatch.org/en/worker-driven-monitoring_2460012 (accessed 1 December 2017).

96 Ibid. The models of worker-centred or worker-driven monitoring are still being tested and defined, so is specific methodology to guarantee not only a better representation of workers in the monitoring process but their own capacity to be the drivers of such a process. Both practice and research on it is lacking and urgently needed.

97 Ibid, and Business, Human Rights and the Environment and International Labour Rights Forum, Report on Worker Driven Monitoring in the Electronics Industry (Hong Kong, April 2017) (2018, in press, on file with the author).
} 
about workplace hazards and rights violations without fearing employer retaliation. ${ }^{98}$ The close relationship of monitors with workers enables these local organizations to detect and understand hard-to-measure violations, such as union repression and discrimination, and vulnerability to other violations such as forced labour and human trafficking. In theory, these kinds of local monitors would be able to react quickly to issues that must be addressed promptly and to stay engaged over a long period of time, when needed, to oversee the process of remedying long-term violations and achieving sustainable compliance. ${ }^{99}$ Electronics Watch has so far engaged local groups in China, Mexico, India, Thailand, Indonesia, the Philippines and the Czech Republic. ${ }^{100}$ Through these organizations it is able to undertake both regional risk assessments and factory compliance investigations. So far, this has led to three regional risk assessments and five factory reports. ${ }^{101}$ All reports are available to affiliates.

\section{E. Remediation and Supply Chain Reform}

The main goal of a labour and human rights standard setting and monitoring system is to improve the working and living conditions of those working in supply chains. Remediation of specific violations is essential and so is reform of conditions that result in such violations. As discussed in the previous section, a common criticism of current monitoring processes is that they do not serve as a basis for remediation of the situation of abuse of workers' rights, nor do they facilitate reparation processes. Even if specific instances get resolved, problems tend to resurface and ultimately auditing and monitoring do not lead to supply chain reform. In line with the UNGPs, mechanisms for remediation are needed when human rights violations occur in corporate environments. Such mechanisms should ideally provide a means by which all relevant parties, including supply chain employees, sub-contractors, the contracted supplier and the consumer - in our analysis, the public buyer - can raise issues and seek resolution and remedies.

The Electronics Watch Contract Conditions allow contracting authorities to employ enforcement actions that not only guarantee contractual compliance by the supplier but ultimately seek to enable the address of specific and endemic problems in the factories monitored. These enforcement actions can be applied gradually, as needed, beginning with informal engagement proceeding to escalation procedures and, as last resort, sanctions. Termination of contracts may not be the most effective tool, as the public buyer would probably lose all leverage over the contractor and its supply chain.

All Electronics Watch monitoring reports contain specific actions recommended for affiliates, ranging from raising 'Worker Rights Alerts' to their contractors demanding compliance plans from them to address the risk identified by monitors within 30 days. Worker Rights Alerts are based on in-person worker complaints, hotline reports, and other forms of worker testimonies. These reports identify actual or potential violations of

98 Electronics Watch Worker Driven Monitoring, note 95.

99 See, for example, Electronics Watch, Electronics Watch Monitoring and Reform Programmes, 2015, http:// electronicswatch.org/monitoring-and-reform_98120.pdf (accessed 1 April 2017), p. 4.

100 Ibid.

101 Electronics Watch Impact and Project Results at a Glance note 87. 
the Electronics Watch Code of Labour Practices in any of the disclosed factories, and recommends steps that factories, contractors, or brands should take to mitigate and prevent risks of violations. Affiliates can use these reports in contractor engagement either to ensure the contractors address the issues adequately in their compliance plans, or, if the issue is not remedied, use escalation or enforcement actions as necessary to ensure corrective action. For example, in July 2016 Electronics Watch recommended affiliates to raise worker rights alerts to contractors providing a series of brands supplying from a specific factory in the Philippines. ${ }^{102}$

Corrective action plans are based on the extensive evidence gathered through off-site worker interviews, interviews with factory management and supervisors, review of factory personnel records and other factory documents. The reports present conclusive findings regarding the potential violations identified in the risk analyses or in related allegations or complaints. If Electronics Watch finds breaches of the Electronics Watch Code of Labour Practices, a corrective action plan is recommended for the factory and the organization would work with the factory management, workers and their representatives, the contractor, and the brand company as necessary, to implement the steps needed to correct the violations.

Affiliates can use these reports and updates on the corrective action plans to hold the contractor accountable for any failure to address contract breaches, and use escalation or enforcement actions as necessary. For example, in September 2016 Electronics Watch recommended affiliates whose contractors provided a specific brand sourcing from the Czech Republic to demand a compliance plan including both short-term and long-term actions, to address all areas of risk identified, which ranged from discrimination, freedom of association, work contracts, working hours, wage payments, housing and transportation and specific concerns regarding migrant workers. ${ }^{103}$

In general, providing evidence of impact, beyond remediation of individual violations, and measuring the capacity of factory monitoring on structural changes over working conditions is very difficult. ${ }^{104}$ So far the activity of Electronics Watch has provided evidence of collaboration between public buyers, its contractors and brands in the sector which shows a considerable potential of public buyers' leverage on the industry. The organization measures its impact to date as improvements in five factories, benefiting more than 50,000 workers and the improvement of supply chain transparency by three brands as the direct response of affiliates' requirements. ${ }^{105}$ For example, there was a sustained two-year engagement between Swedish County Councils with the brand Dell, who was an IT provider to the Councils. The Swedish Councils' intervention included declaring a standstill on additional purchases of Dell products, which amounted to a de facto termination of the contract. This led to the design of specific transparency and due diligence procedures in order to address concerns over labour rights and safety issues in certain factories in China. In 2016, the UK purchasing organization London Universities Purchasing Consortium (LUPC) and others successfully engaged with a

102 This report is only available to the affiliates - on file with the author.

103 This report is only available to the affiliates - on file with the author. At the time of writing affiliates were still engaged in taking these measures.

104 For example, Locke, note 2.

105 Electronics Watch Impact and Project Results at a Glance, note 87. 
series of electronics brands to end a practice of forced student labour in factories providing servers to such brands. ${ }^{106}$

\section{Conclusion}

This article has argued for the potential for capitalizing on the significant leverage that public buyers have over corporate practices in the supply chain and to serve as a tool to promote respect and protection of human rights. The Electronics Watch initiative provides an innovative example of practices that bring state purchasing to the centre of the state obligation to protect the human rights of those who produce their products. Through this model the economic leverage of public buyers can be articulated into a transformative tool for working conditions in global supply chains. It is rapidly consolidating through the inclusion its Contract Conditions in several European ICT procurement contracts, which means that suppliers are assuming contractual commitments to exercise due diligence over their supply chain and engage in remediation when breaches have been identified. Local monitoring organizations that integrate its network are in place and reporting on working conditions and supplier compliance with international and national standards specially tailored to the electronics industry. Buyers, suppliers and brands are collaborating to find solutions in specific factories but also to establish better practices in the industry. The ethos of Electronics Watch is to serve as an instrument of supply chain transformation and therefore facilitate supply chain reform. This alliance, between civil society and public buyers, is based on multi-stakeholder actor engagement but is firmly anchored in the legal responsibility that contractual clauses bring. It revolves around the definition of human rights due diligence as a measurable process: an effective process that has the capacity to bring about positive change to the industry and its supply chain practices, ultimately contributing to the improvement of life and working conditions of those who produce the goods we buy. The infrastructure to do this has been set up, and further implementation of the Electronics Watch Labour Code and Contract Conditions, and evaluation of the impacts of such activity, is now needed to validate this model, both for this specific industry and for supply chains more widely.

106 LUPC's action was prompted by the Danwatch investigation into the factory of the company Wistron Corporation in Zhongshan (China), Danwatch, 2015, note 26. The case study of this collaboration is confidential and not openly available (on file with the author). LUPC used Electronics Watch reports and recommendations in their engagement with the factory and the brands. 